ISSN1027-5495. Functional Materials, 23, No.1 (2016), p. 146-149.

doi:http://dx.doi.org/10.15407/fm23.01.146

(C) 2016 - STC “Institute for Single Crystals"

\title{
Influence of repair cost on different front energy absorbing structure to automobile low-speed impact
}

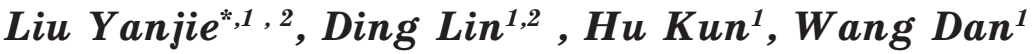 \\ ${ }^{1}$ School of Civil Engineering, Heilongjiang University, \\ Harbin 150086, P.R. China \\ ${ }^{2}$ Northeast Frost Civil Engineering Key Laboratory of Heilongjiang \\ University, Harbin 150086, P.R. China
}

Recieved 15 August, 2015

\begin{abstract}
The good Automobile front energy absorbing structure is an important part in automotive crash safety. The better performance of absorbing structure, the lighter damage of vehicles and other components, and the lower automotive collision repair cost.. In this paper, the motor vehicle energy-absorbing structure was completed by apply Finite Element (FE) method. This FE method was carried out apply the software LS-DYNA. Energy-absorbing structure of automobile usually made of thin wall metal tube. The tube was using of aluminum alloy and carbon steel material. Emphasis was focused upon discovery an optimum lateral section shape of the thin wall metal tube in order to enhance the crashworthiness. Some types of lateral section were compared and researched. Results show that the repair cost of the tube enhanced obviously when aluminum alloy lateral cross section was employed.

Keywords: Automobile, low velocity impact, energy absorbing structure, energy absorption characteristic, repair cost.

В работе структура, поглощающая энергию была получена применением метода конечных элементов. Этот метод был применен с использованием программного обеспечения LS-DYNA. Поглощающая энергию структура автомобиля обычно сделана из тонкостенной металлической трубки. Трубка была из алюминиевого сплава и углеродистой стали. Акцент был сделан на определении оптимальной фрормы поперечного сечения тонкостеночной металлической трубки для увеличения удароустойчивости. Было проведено сравнительное изучение некоторых типов поперечных сечений. Результаты показывают, что стоимость ремонта заметно увеличивалась при использовании поперечного сечения алюминиевого сплава.
\end{abstract}

Вплив на вартість ремонту різних структур для поглинання фронтальної енергії при ударі автомобіля на низькій швидкості. Лю Яньцзе, Дін Лінь, Ху Кунь, Ван Дань.

В роботі структура, що поглинае енергію, булла визначена з використанням методу скінчених елементів. Цей метод було застосовано з використанням программного забезпечення LS-DYNA. Структура для поглинання енергії звичайно зроблена з тонкостінних металевих трубок. Трубки були з алюмініевого сплаву та вуглецевої сталі. Акцент було зроблено на визначенні оптимальної форми перерізу тонкостінної металевої трубки для підвищення стійкості до удару. Було проведено порівняльне дослідження деяких типів перерізів. Результати показують, що вартість ремонту помітно збільшуеться при використанні поперечних перерізів з алюмінієвого сплаву. 


\section{Introduction}

The motor vehicle collision has been an important issue in automobile investigation field, due to traffic accident is one of the most serious social problems all over the world. In China, the injuries and death caused due to vehicles high speed impact, has been get attention. But, low- velocity collisions usual occur in crowded cities $[1,2]$. Low speed impact didn't get the attention of people, because no personnel injury. It is therefore of great necessary to research the technical problems involved in low speed impact.

Energy absorbing structure (see Fig.1), is a very important vehicle components. It is not only to protect car occupants and external pedestrian safety, reduce the degree of damage effect, but also to reduce the damage to vehicles and other components. It can also reduce the repair cost of vehicle in the crash occurred.

In this present article, the energy-absorbing structure of automobile in low-speed impact was researched. And repair cost on automobile components is proposed.

\section{Inflence ofdifferent materials on repair cost}

\subsection{Model Building}

In this paper, energy absorbing structure was made of thin walled tubes, and a finite element model is adopted by apply the software Hypermesh $[3,4]$. The axial low speed collision of the circular lateral section tube $(\varnothing 90 \mathrm{~mm}$ diameter, $1.65 \mathrm{~mm}$ thick and $160 \mathrm{~mm}$ long) was researched firstly.

The circular lateral section mental tubes, is a ordinary type of automobile energy absorbing structure since it is relatively cheap, efficient and versatile for absorbing energy $[5,6]$. The finite element mesh of circular tube is exampled in Fig. 2. A stiff plate, placed on the top of the circular tube(see fig. 2), is $1000 \mathrm{~kg}$, and axially impacted speed of $4.44 \mathrm{~m} / \mathrm{h}$.

\subsection{Main Influencing Factor to Crash- worthiness}

There are many factors that can influence crashworthiness characteristics of energy absorbing structure in collision simulation process, including energy absorbing structure shape, wall thickness, materials and so on, in which material properties has great effects on device characteristics $[7,8]$.

\subsection{Material Selection}

Along with the quick development of vehicle industry, the light materials have been used in the motor vehicle [9]. Due to the compression

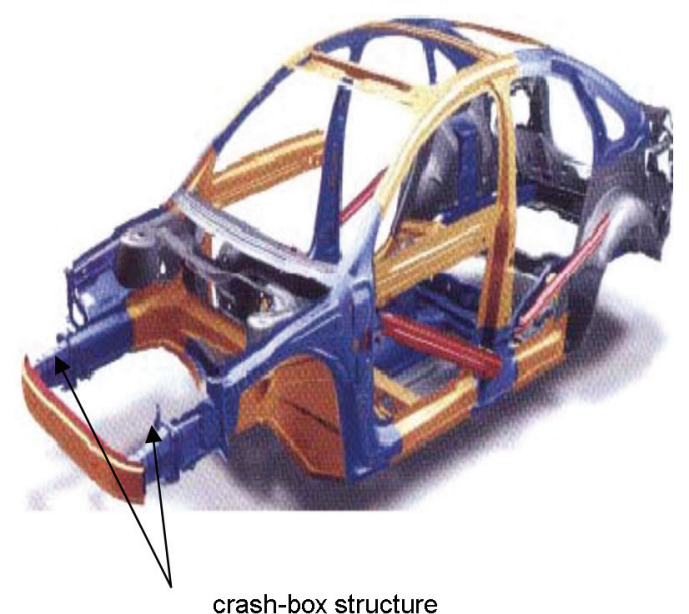

Fig. 1. Position of crash-box in the car body.

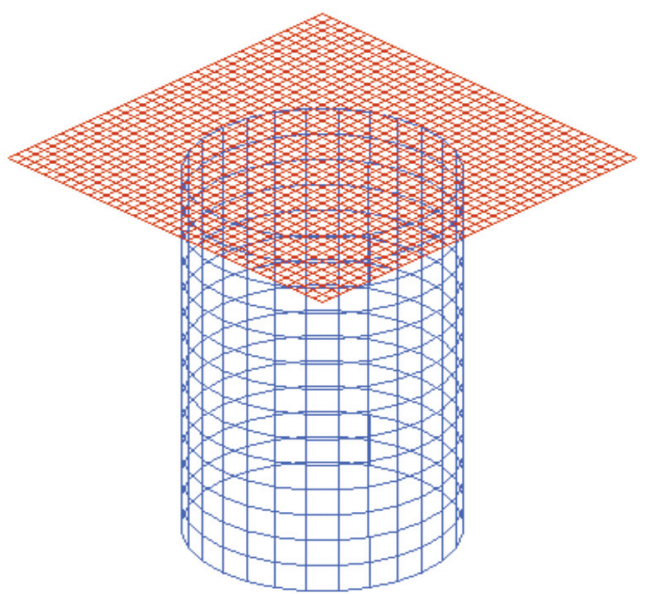

Fig. 2. Mesh model of the circular tube.

Table 1. Material Characteristics

\begin{tabular}{|c|c|c|c|c|}
\hline & $\begin{array}{c}\text { yield } \\
\text { strength } \\
(\mathrm{MPa})\end{array}$ & $\begin{array}{c}\text { Density } \\
(\mathrm{kg} / \mathrm{mm})\end{array}$ & $\begin{array}{c}\text { Pois- } \\
\text { son } \\
\text { ratio }\end{array}$ & $\begin{array}{c}\text { Young's } \\
\text { modu- } \\
\text { lus } \\
(\mathrm{GPa} .)\end{array}$ \\
\hline $\begin{array}{c}\text { Carbon } \\
\text { sheet }\end{array}$ & 430 & $\begin{array}{c}7.85 \mathrm{x} \\
10-6\end{array}$ & 0.3 & 210 \\
\hline $\begin{array}{c}\text { Alumi- } \\
\text { num alloy }\end{array}$ & 455 & $\begin{array}{c}2.81 \mathrm{x} \\
10-6\end{array}$ & 0.33 & 71 \\
\hline
\end{tabular}

moulding, aluminum alloy material is widely concerned.

In this article, the metal tube was simulated using aluminum alloy of 7075 aluminum alloy and carbon steel. Table 1 provides the main material characteristics parameters .

\subsection{Crashworthiness Comparison}

On the basis of Fig.2 FE modeling method, apply the same lateral section dimension and edge conditions, aluminum alloy and carbon steel tube was imitated. Comparison results of impact carbon steel and aluminum alloy crashbox was displayed in Fig. 3 and 4 . The crest 


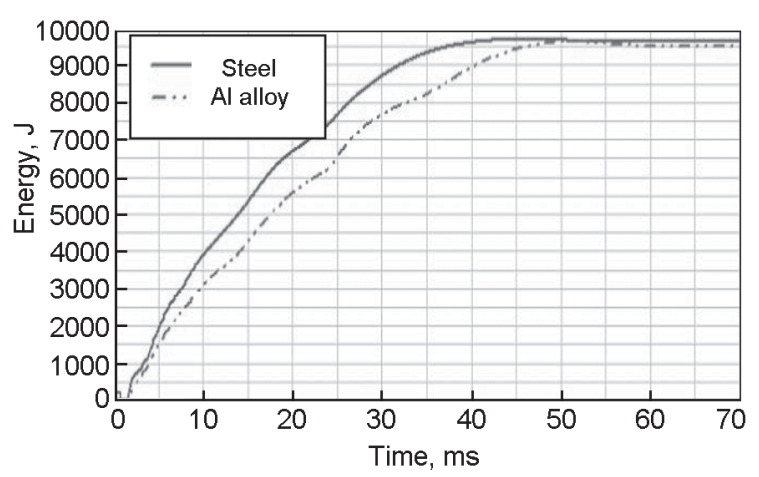

Fig. 3. Energy vs. time curve .

Table 2. Comparison of energy absorbing characteristics

\begin{tabular}{|c|c|c|}
\hline & $\begin{array}{c}\text { Crest value } \\
\text { impact load }(\mathrm{kN})\end{array}$ & $\begin{array}{c}\text { Crest value } \\
\text { load reduction }\end{array}$ \\
\hline Carbon sheet & $311.00 \mathrm{KN}$ & \\
\hline $\begin{array}{c}\text { Aluminum } \\
\text { alloy }\end{array}$ & $273.66 \mathrm{KN}$ & $12 \%$ \\
\hline
\end{tabular}

value of impact load with different material tubes are displayed in Table 2. As a result, we find that all of the energy is almost absorbed to the two materials, because the energy curve eventually tends to a horizontal line. The crest value impact loads of tubes diminished when used different material. The crest value impact loads of aluminum alloy tube diminished $37.34 \mathrm{kN}$.

So come to the conclusion, the aluminum alloy material energy absorbing structure has excess than carbon steel materials materials energy absorbing structure.

\section{Influence of different structures on repair cost}

\subsection{Model Building}

As a rule, the energy absorbing structure have two indexes to evaluate the energy absorption characteristics. One is the energy by plastic deformation of oneself occupy a large proportion in the entire energy systems, another is impact load -displacement curve stabilize and no too big crest value force [10].

\subsection{Structures Selection}

In this article, five types of thin-walled metal tubes were researched and contrasted.The tube circumference is equal, the finite element model of all the five tube and geometries were shown in Fig. 5, where, (a) square, (b) rectangle, (c) circular, (d) hexagon, and (e) octagon.

All the tubes are $1.65 \mathrm{~mm}$ thick, circumference $280 \mathrm{~mm}, 120 \mathrm{~mm}$ long and same 7075aluminum alloy material was applied. The material char-



Fig. 4. Impact load vs. displacement.

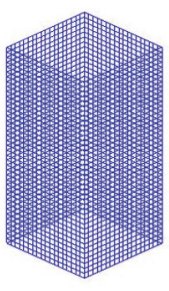

a)

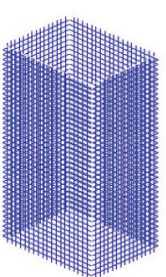

b)

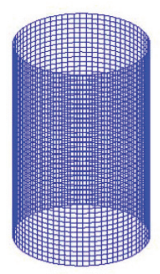

c)

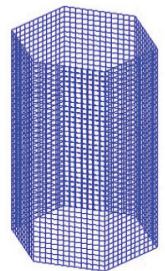

d)



e)
Fig. 5. Main Mesh model of the tube

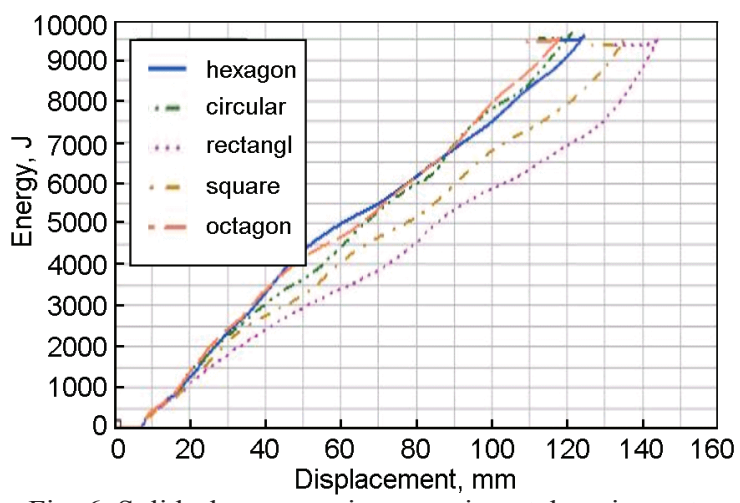

Fig. 6. Solid-plug conveying experimental equipment.

acteristics are showed Table 1. According to the same boundary conditions and FE modeling method, five aluminum alloy metal tube was emulated.

\subsection{Crashworthiness Comparison}

Contrast the simulation results (the impact load vs. displacement, and energy vs. displacement) as displayed in Fig.7and Fig.8, we draw the conclusion that the best lateral section is 


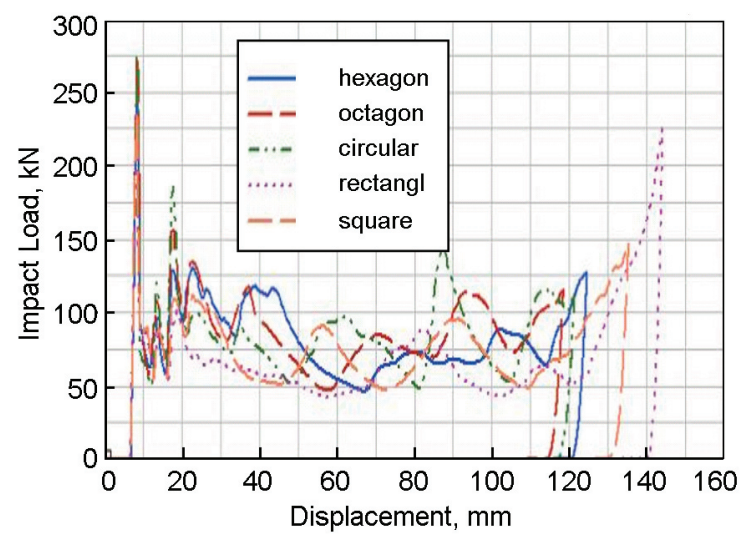

Fig. 7. Solid-plug conveying experimental equipment.

the square section. The crest value of the impact load to different lateral section shape tube is (a) $237.433 \mathrm{kN}$, (b) $273.66 \mathrm{kN}$, (c) $272.81 \mathrm{kN}$, (d) $276.27 \mathrm{kN}$, and (e) $238.68 \mathrm{kN}$ separately. All of them exceed the permissible value, $185 \mathrm{KN}$. Among them, the most smallest one is square section. We concluded that the thin-walled metal tube of square lateral section can be further optimization design.

\section{Conclusions}

Low speed collision occurs, the front energy absorbing structure crashworthiness is poor ,vehicle will damage front longitudinal beam. The front longitudinal beam repair costs are usually the bumper and the energy absorption component replacement costs several times. The front longitudinal beam repair process is complex, the cost is high, and vehicle safety will be affected after the repair .

We therefore conclude that aluminum alloy energy absorbing structure of square cross section crashworthiness is good, the model selection, will reduce the cost of repair.

\section{Acknowledgements}

This work was financially supported by the Heilongjiang Education Committee Science and Technology Project (12541615), and Harbin Science and Technology Bureau Project (RC2015QN001020).

\section{References}

1. Z. W., Qiangjun Ma, Chengyu Li, J. Clean.Prod., 91, $305,2015$.

2. A. C. Croft, T. R. Eldridge, J.Chirop. Medicine, 10, 141,2011

3. J. L. Forman, F. J. Lopez-Valdes, S. Duprey, Accid. Anal.Prev., 80, 7, 2015.

4. A. Ghadianlou, S. Bin Abdullah, 67, 25, 2013.

5. W. Gao, M. Zang, Eng. Anal. Bound. Elem.., 42, 2, 2014.

6. Srinivas Padala, Minh Khoi Le, Sanghoon Kook, Evatt R. Hawkes, Appl. Therm. Eng., .52, 24, 2013

7. E.A. Mathews, S. Balasubramanian, T. Seacrist, et.al., J. Electromyogr. Kines, 23,1206, 2013.

8. V. Krishnan, , E.Kastrouni, V. D. Pyrialakou, et.al., Transp. Res.Part C: Emerg.Techn., 54, 131, 2015.

9. A. Alomari, S.Aldajah, S. Hayek, et.al., Mater. Design, 47, .836, 2013.

10. H. Chul Kim, D. Kil Shin, J. Ju Lee, J. Beom Kwon, Comp. Struct., 112, 1, 2014. 